\title{
Origin of three peridotite suites from Horoman peridotite complex, Hokkaido, Japan; Melting, melt segregation and solidification processes in the upper mantle.
}

\author{
NatSUKO TAKAHASHI \\ Department of Earth Sciences, Faculty of Science, \\ Kanazawa University, Kanazawa 920
}

\begin{abstract}
The Horoman peridotite complex, Hidaka belt, Hokkaido, northern Japan, is composed of three peridotite suites which have distinct petrographic characteristics. The first is the Main Harzburgite-Lherzolite (MHL) suite, which occupies the most part of the Horoman peridotite complex. The MHL suite consists of harzburgite, spinel lherzolite and plagioclase lherzolite, which form a layered complex with gradational layer boundaries. Two-pyroxene spinel symplectite, which is interpreted as a chemically modified garnet pseudomorph, occurs in spinel and plagioclase therzolites. The MHL suite is of typical residual origin after various degrees of magma extraction, which resulted in wide chemical variations. The second, the Banded DuniteHarzburgite $(\mathrm{BDH})$ suite, consists of conspicuously layered dunite, harzburgite and olivine orthopyroxenite with sharp layer boundaries. The BDH peridotites are probably exotic blocks within the MHL suite. Mineralogical characteristics of the BDH suite suggests that it is a cumulate from a high-Mg magma (e.g., high-magnesian andesite). The third, the Spinel-rich Dunite-Wehrlite (SDW) suite, consists of dunites containing abundant large oblate chromian spinel grains. The dunite becomes locally wehrlitic and contains clinopyroxene up to $8 \%$. The SDW occurs in the MHL harzburgite zones as layers with maximum thickness of $15 \mathrm{~m}$. The layer boundaries with the harzburgite of the MHL suite are generally sharp. The petrographical and mineralogical characteristics show that the SDW is a cumulate from a magma segregated from the surrounding MHL suite. The melt segregation may be caused by formation of cracks in upwelling mantle materials just before the mantle materials spreading away from the upwelling center as a corner flow. A series of layered residual peridotite (MHL suite) zones, of which degree of melt extraction increases inwards, formed around the SDW dikes.
\end{abstract}

\section{Introduction}

Several mechanisms of the melt segrega. tion in the mantle have been proposed. There are, however many controversies on this matter (e.g., Sleep, 1974, 1988; Nicolas, 1986, 1989), and no definitive conclusions have yet been reached. In order to understand the melt segregation process, volcanic rocks have been usually investigated as "frozen magma" from the upper mantle. Those magmas, however, have experienced shallower events, such as fractional crystallization, magma mixing and crustal contamination, and tend to lose important information on the upper mantle as they rise to the earth's surface. More direct information on the upper mantle processes can be obtained through investigations of the mantle materials, even though they have been formed as a result of "time integration" of various processes.

Alpine-type peridotite masses are commonly known as mantle fragments which have been uplifted and exposed on the earth's surface by large tectonic events. Although these rocks

(Manuscript received, May 29, 1990 ;

accepted for publication, February 6, 1991

* Present address: Geological Institute, Faculty of Science, University of Tokyo, Tokyo 113 
are often affected considerably by deformation and alteration processes during or after their emplacement, they can give us useful informa tion on melting and related processes in the upper mantle.

The Horoman peridotite complex in the Hidaka belt, Hokkaido, northern Japan, is well known to have a characteristic layered structure. Several studies have been carried out on this complex. (i.e. Nagasaki, 1966 ; Niida, 1974, 1975, 1984; Obata and Nagahara, 1987). After the pioneering works of Nagasaki (1966) and Niida (1984), Obata and Nagahara (1987) presented a interesting model for the origin of the gradual layering of the lower part of the complex; they interpreted that the layering represents upward moving melt wave which was frozen as an alternation of highly depleted residual and melt-enriched fertile zones. Their idea of the origin of layering looks very attractive because it provides a plausible explanation for melt segregation processes. In contrast, Takahashi (1988MS, 1991) performed detailed petrological works and found that the Horoman complex is composed of quite various kinds of ultramafic rocks, which had been produced by time-integrated igneous processes in the upper mantle. Horoman complex may have undergone tectono-magmatic evolution in the upper mantle, and its petrologic diversity can not be explained by the simple one-stage model of Obata and Nagahara (1987).

The purpose of this paper is to identify and characterize three distinct peridotite groups from the Horoman complex, which have been treated as a single group by previous workers (i.e. Niida, 1984 ; Obata and Nagahara, 1987). This paper discusses a history of the Horoman peridotite complex including melting, melt seg regation and solidification, using several constraints obtained through detailed petrologic studies of these three peridotite groups.

\section{Geological background}

The Horoman peridotite complex is located at the southern end of the Hidaka metamorphic belt in Hokkaido, northern Japan. The Hidaka belt is characterized by a low-pressure type metamorphism (Miyashiro, 1961). This complex belongs to the Main Zone of the Hidaka belt (Komatsu et al., 1986). It is approximately $8 \mathrm{~km} \times 10 \mathrm{~km}$ in size, and is in fault contacts with surrounding various metamorphic and igneous rocks. The Horoman complex is the largest of all peridotite bodies in the Hidaka belt and consists of various kinds of peridotites. The complex is dominated by ultramafic rocks, but small amounts of gabbroic rocks are also present as layers, especially in the upper part of the complex. The gabbroic rocks increase in abundance upwards. This complex is a stratified complex and has a total thickness of approximately $3000 \mathrm{~m}$ (e.g., Niida, 1974). The rocks are well exposed and the degree of serpentinization is generally very low. The Main Zone of the Hidaka belt is interpreted to be a mantlecrust slice of an island arc or a continental, which was thrusted up during collision between the Eurasia plate and the North America plate in the late Miocene to Pliocene (Komatsu et al, 1986).

\section{Three petrographic suites of the $\mathrm{Ho}_{0}$ - roman peridotite}

The central-southern part of the complex was mainly investigated. The lithological map of this area is shown in Fig. 1. The modal compositions of peridotites in the investigated area are given in Fig. 2. Three distinct groups of peridotite are identified according to the differences in the modal composition, mode of occurrence and mineralogical characteristics as will be described below. They are Main Harzburgite-Lherzolite suite, Banded Dunite-Harz- 


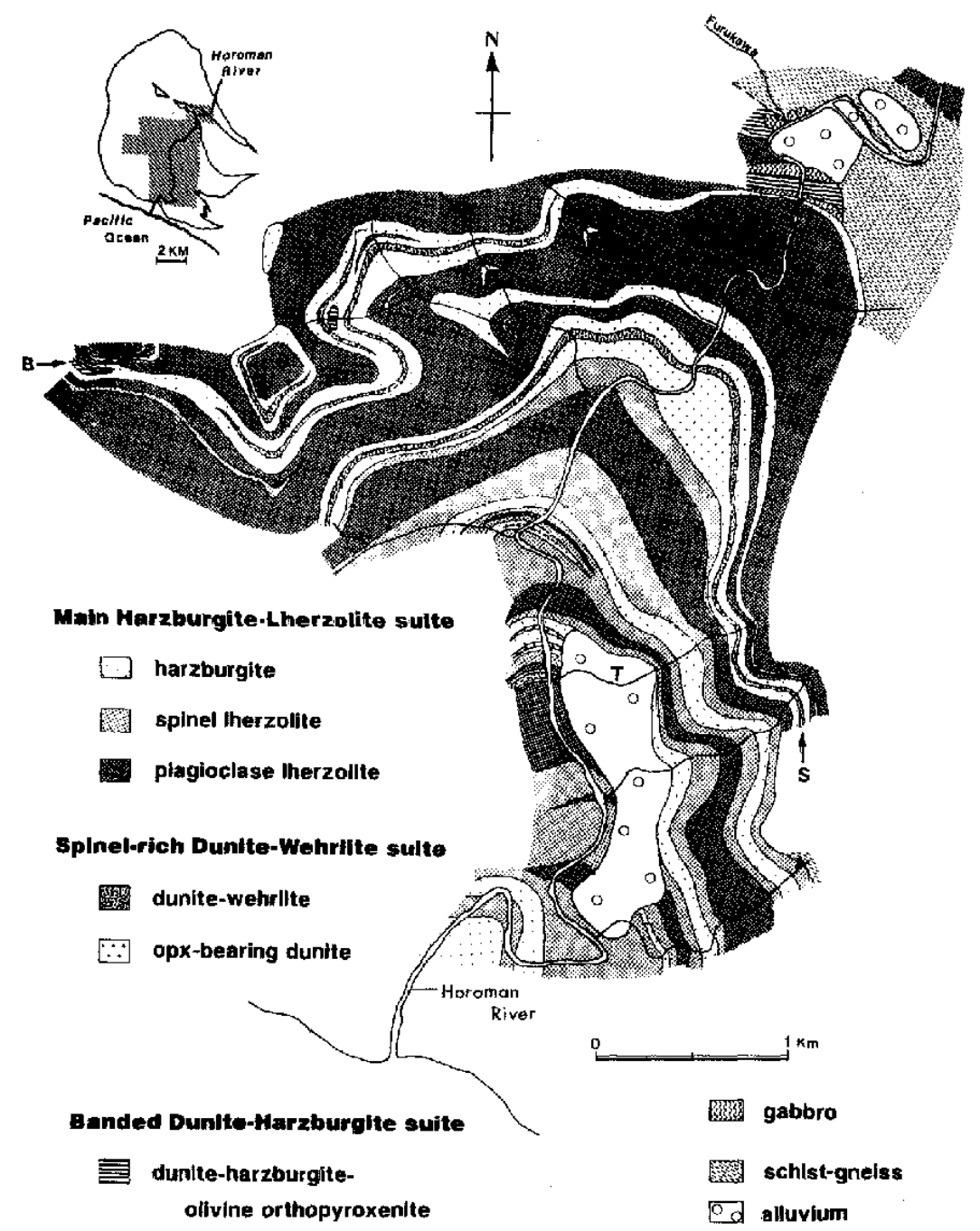

Fig. 1. Lithological map of the southern part of the Horoman peridotite complex. T, Takinosawa. B and $\mathrm{S}$ with arrows indicate the locality of BDH of Fig. 3 and the thickest SDW layer, respectively.

burgite suite and Spinel-rich Dunite-Wehrlite suite, and are denoted as MHL suite, BDH suite and SDW suite, respectively in this paper.

The Main Harzburgite-Lherzolite (MHL) suite consists of layered harzburgite, spinel lherzolite and plagioclase lherzolite (Fig. 2) with gradual lithological boundaries (Niida, 1984 ; Obata and Nagahara, 1987). The thickness of individual layer is typically less than a few hundred meters. It occupies the most part of the Horoman complex (Fig. 1), and corresponds to the "Main Peridotite Suite" of Takahashi et al. (1989). Previous workers (e.g. Niida, 1984 ; Obata and Nagahara, 1987) exclusively dealt with the rocks of this suite. Most of the "dunite" reported by previous workers are actually harzburgite, because they usually contain more than 5 volume \% of orthopyrox. 


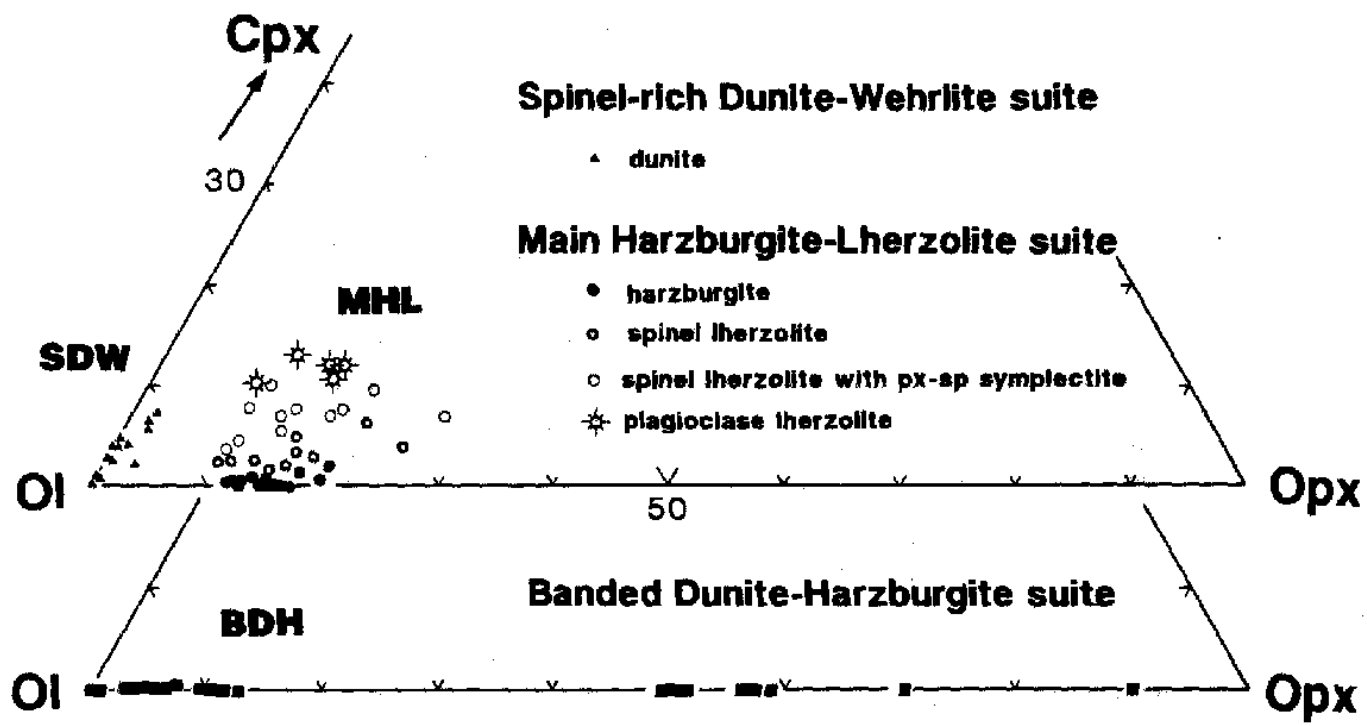

Fig. 2. Modal compositions of the Horoman peridotites. Note that harzburgite and lherzolite in this paper are defined on the basis of the ratio of clinopyroxene and orthopyroxene $(\mathrm{Cpx} / \mathrm{Cpx}+$ $0 p x)<0.1$ for harzburgite).

ene.

Dunite containing more than 90 volume \% of olivine is very rare in the MHL suite.

The Banded Dunite-Harzburgite (BDH) suite corresponds to the "Furukawa Peridotite Suite" of Takahashi et al. (1989). One of the peridotite bodies occurring along Furukawa, one of tributaries of the Horoman river, in the northeastern part of the complex, was first described by Arai and Takahashi (1986). This suite is composed of refractory dunite, orthopyroxene-rich harzburgite and olivine orthopyroxenite which are almost free of clinopyroxene (Fig. 2). It is characterized by a conspicuous modal and/or phase layering with sharp boundaries; individual layers range from a few centimeters to a few meters in thickness (Fig. 3). The BDH suite occurs in the upper part of the MHL suite as several discontinuous bodies

Fig. 3. A column of the BDH peridotite mass from one of the localities in the Apoi area. L, lowest gabbro band. Note that the banded SDW peridotites occur above the BDH peridotite mass.

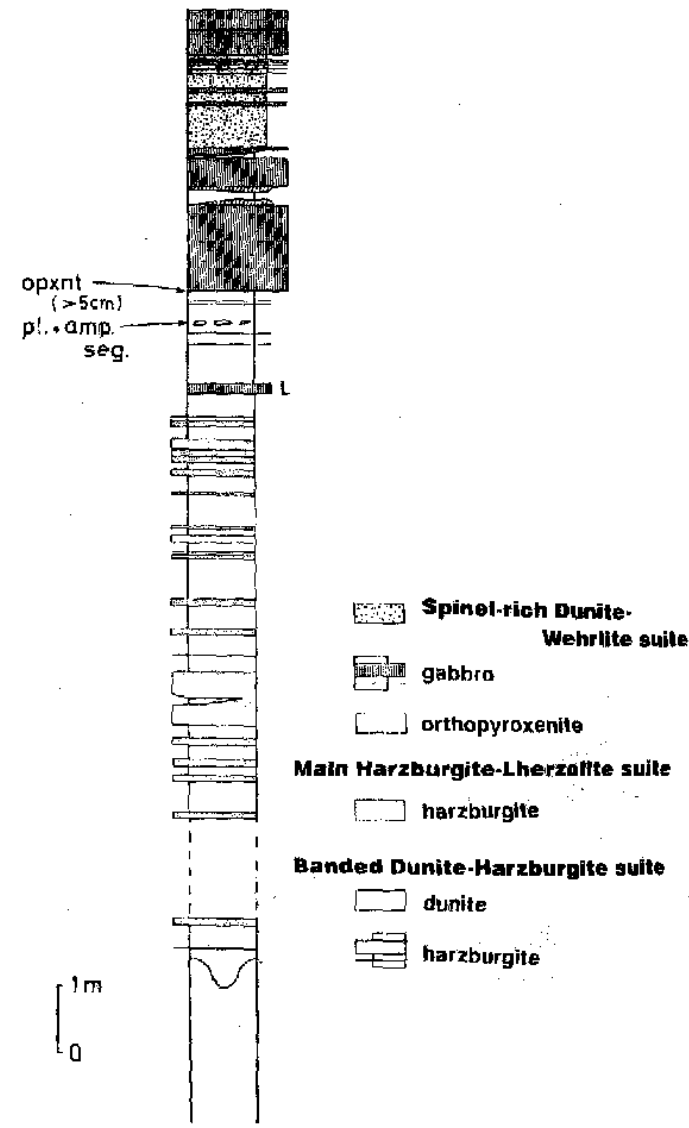




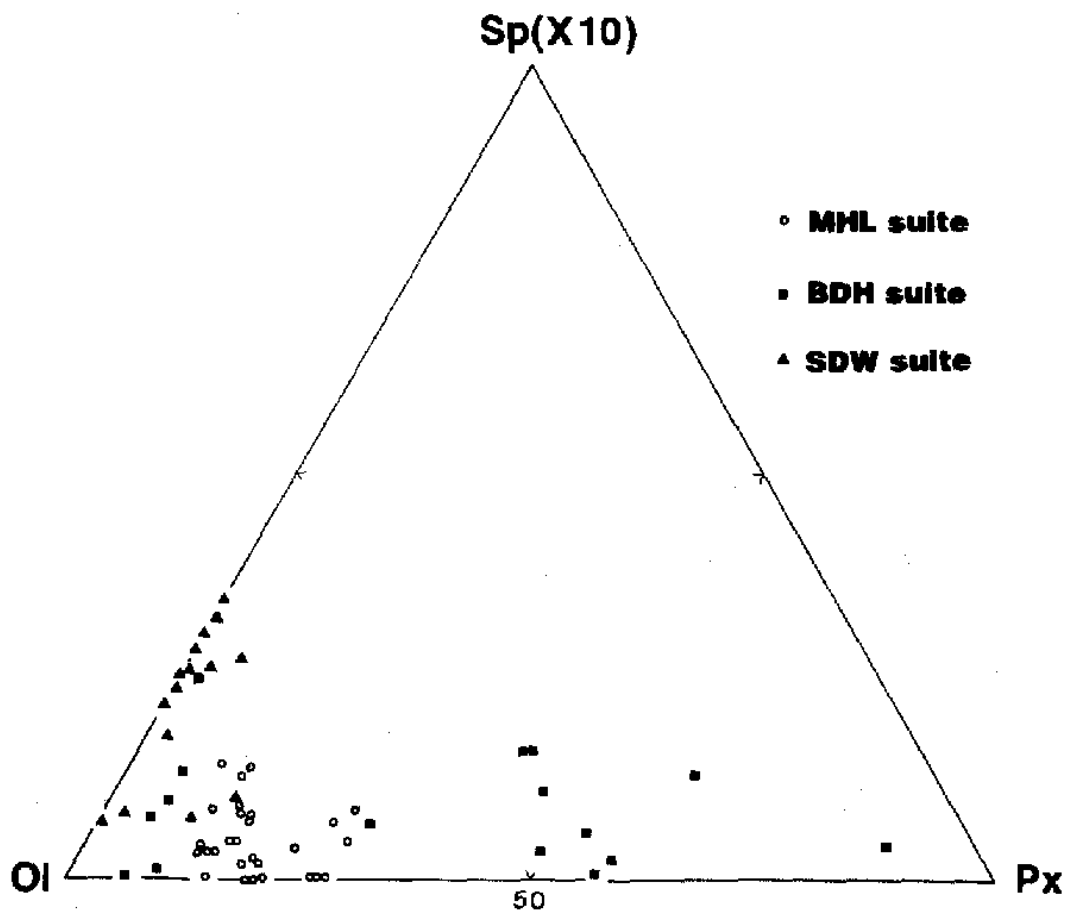

Fig. 4. Modal composition, $10 \times$ spinel (Sp)-olivine (Ol)-pyroxenes ( $\mathrm{Px}$ ), of the Horoman peridotites.

in a few specific horizons (Fig. 1).

The Spinel-rich Dunite-Wehrlite (SDW) suite is composed mainly of dunite with local wehrlitic portion (Fig. 2). The SDW suite corresponds to the "Cumulus Dunite Suite" of Takahashi et al. (1989). This suite usually contains abundant (sometimes up to 5 volume \%) large (up to $4 \mathrm{~mm}$ in diameter) oblate chromian spinel grains (Fig. 4). The SDW suite occurs as continuous layers remarkably concordant with the MHL layering. It is present in the MHL harzburgite zone without exception. The thickest layer (about 14 to 16 $m$ in thickness) in the middie horizon of the complex is traceable over at least about $4 \mathrm{~km}$ along the strike from the eastern margin to the ceriter of the Horoman complex. In the upper part of the complex, the SDW alternates with gabbroic layers with sharp boundaries.

\section{Geology and petrography}

IV-I The MHL suite

The MHL suite shows a wide lithological variation; harzburgite gradually changes into plagioclase lherzolite through spinel lherzolite in terms both of the modal abundance and of mineral chemistry (Figs. 2 and 5). The total modal percentage of pyroxenes and the modal ratio of clinopyroxene to orthopyroxene monotonously increase from harzburgite to plagioclase lherzolite.

Dunite is very rare in the MHL suite (Figs. 2 and 4$)$. The harzburgite layer locally contains patchy dunitic part (about several square centimeters across), where orthopyroxene seems to be accidentally rare.

The two-pyroxene spinel symplectite (e.g., Kushiro and Yoder, 1966 ; Tazaki et al., 1972) occurs in comparatively fertile spinel therzolite and rarely in plagioclase lherzolite. The 


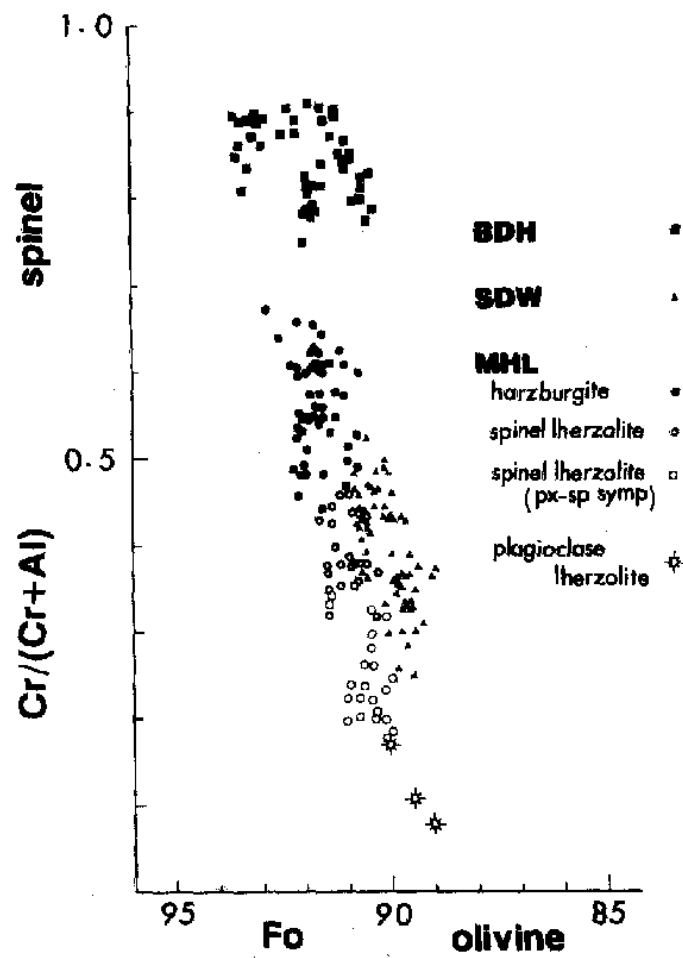

Fig. 5. Relationships between Fo content of olivine and $\mathrm{Cr} /(\mathrm{Cr}+\mathrm{Al})$ atomic ratio of coarse discrete spinel in the Horoman peridotites. Symbols are the same as in Fig. 2 .

symplectite-bearing spinel lherzolite contains much more clinopyroxene than the symplectite-free one (Fig. 2). The symplectite is usually surrounded with a coarser-grained aggregate of the same minerals $>0.01 \mathrm{~mm}$ across) as symplectite constituents (< several microns in width). This aggregate is called "fine-grained aggregate" in this paper. Detailed petrographical descriptions of the symplectite are available from Takahashi and Arai (1989).

The transitions from the symplectite-bearing lherzolite to the symplectite-free one in the field are classified into two types. One type is a gradual layer-to-layer transition in large scale (Niida, 1984). The symplectite-free spinel lherzolite often occurs between harz- burgite and symplectite-bearing lherzolite. In such symplectite-free spinel therzolite layers, ellipsoidal aggregates composed of coarse spinel and orthopyroxene grains are often found instead of the symplectite. The other type is a small-scale layering with sharp boundaries. Thin layers (several tens of centimeters to a few meters) of the symplectite-free lherzolite are frequently present in the symplectitebearing lherzolite, but the layers of the latter are rarely present in the former (Takahashi, 1988MS).

It is noteworthy that the grain size of spinel in symplectite increases and the abundance of symplectite decreases as the peridotite becomes more depleted. In the spinel lherzolite layer, size of spinel in the symplectite gradually grows larger as well as volume of symplectite becomes smaller, as it leaves from the bound. ary with plagioclase lherzolite.

The symplectite occurring in spinel lherzolite near the boundary with plagioclase lherzolite consists not of two pyroxenes + spinel but of olivine + spinel + plagioclase $+/-$ orthopy. roxene. The spinel is surrounded by a thin film of plagioclase. This symplectite gradually changes into very fine-grained aggregates of olivine, spinel and plagioclase and/or orthopy. roxene (Takahashi and Arai, 1989). These aggregates gradually change further into thin seams (about $0.8 \mathrm{~mm}$ thick) in plagioclase lherzolite. The seams in plagioclase lherzolite locally include partly disintegrated equivalents of the fine-grained aggregates.

Another important occurrence of symplectite is a rounded inclusion in a coarse orthopyroxene porphyroblast (Takahashi and Arai, 1989). The inclusion is an ellipsoid elongated parallel to the lineation of the host rock. The symplectite inclusion is discrete and is free of a fine-grained aggregate fringe. The inclusion exhibits a polygonal outline in a section vertical to the lineation, which suggests a cross 
section of the garnet dodecahedron. The twopyroxene spinel symplectite in plagioclase lherzolite is only found as an inclusion in orthopy. roxene.

\section{$I V-2$ The $B D H$ suite}

Rocks of this suite are characterized by conspicuous layering with sharp boundaries and a strong deformation exhibited by elongated and flattened spinel grains ( $1 \mathrm{~mm}$ in thickness and several centimeters in length). Olivine is coarse (approximately $5 \mathrm{~cm}$ in diameter) and is strongly deformed. It is recrystallized into aggregates of smaller grains (commonly $0.2 \mathrm{~mm}$ in diameter) along subgrain boundaries. The coarse olivine grains have spinel lamellae. Thin parallel fractures are observed in the flattened and elongated spinel grains. Those fractures are vertical to the lineation and are filled by olivine grains. Spinel is almost opaque under the microscope. It is noteworthy that the $\mathrm{BDH}$ suite is almost clinopyroxenefree (Fig. 2). Discrete clinopyroxene grains are very rare except near the gabbroic rocks as described later. Minute clinopyroxene grains occur very locally at the rim of coarse orthopyroxene grains.

The bodies of $\mathrm{BDH}$ suite have been recognized from five localities which can be grouped into two areas. One is the Horoman river area, where dunite layers are predominant. The other is the Apoi area, where a conspicuous banding of dunite and harzburgite is developed. The gabbroic rocks are always associated with the BDH peridotite except for one locality of the Apoi area.

The BDH suite in the Horoman river area shows a weak layering; a few layers of olivine orthopyroxenite and harzburgite (several centimeters to a meter in thickness) occur in a thick dunite layer (several meters in thickness). In this locality, three bands of gabbroic rocks are found in peridotites. They have almost a similar mineralogy with slight but critical differences. Olivine, clinopyroxene, plagioclase and kaersutite are always present in these gabbros. In the lower gabbro band, magnetite and very small amount of orthopyroxene are present. Thin irregular clinopyroxene-rich seams are found in the $\mathrm{BDH}$ peridotites near the contact with the lower gabbro. The harzburgite of the $\mathrm{BDH}$ becomes websteritic, that is, clinopyroxene increases instead of olivine only near the contact of the lower gabbro. The middle gabbro layer generally has magnetite and the marginal part near the contact with the BDH has higher amounts of clinopyroxene with rare orthopyroxene. It is noteworthy that the BDH commonly shows porphyroclastic texture but has equigranular texture (Mercier and Nicolas, 1975) only near the contact with the middle gabbro. The upper gabbro layer, with orthopyroxene-rich margins, has orthopyroxene and ilmenite. A dunite lens, which is strongly serpentinized, was found in the upper gabbro. An orthopyroxenite layer (about $5 \mathrm{~cm}$ in thickness) is found at the contact between the $\mathrm{BDH}$ suite and the upper gabbro. The BDH suite near the gabbroic rocks contains $\mathrm{Ti}$-rich minerals such as rutile, ilmenite, titanite, kaersutite and Ti-pargasite. Ti-rich metasomatized peridotites around the gabbros will be described in a separate paper.

In the Apoi area, the layering is conspicuous in the BDH mass (Fig. 3). Thickness of harzburgite layers in dunite ranges from 2 to 80 $\mathrm{cm}$, and the boundaries are very sharp. The contact between the BDH and the MHL can be observed in this area (Fig. 3). The boundary between the $\mathrm{BDH}$ and the underlying MHL is weakly undulated. Towards the contact with the $\mathrm{BDH}$, the MHL harzburgite tends to become slightly poor in orthopyroxene. However, the contact is sharp with a modal gap of orthopyroxene (>4volume\%). There are many faults in the BDH suite peridoties, which are sometimes strongly deformed near the 
faults. In the upper part of the $\mathrm{BDH}$ mass, some gabbroic bands parallel to the $\mathrm{BDH}$ layering accur (Fig. 3). The lowest gabbro band (about $20 \mathrm{~cm}$ in thickness and is more than $3 \mathrm{~m}$ in length) has clinopyroxene-rich margins and tips one of which is splitted into two for several tens centimeters. About a meter above the gabbro band, clinopyroxene-rich seams and many clinopyroxenitic bands (several centimeters in thickness) are found in the BDH dunite (Fig. 3). Between these bands, irregular segregations (maximum size $5 \times 3 \mathrm{~cm}$ ) com. posed of plagioclase and kaersutite are frequently found. The BDH mass with pyroxenite seams and bands is overlain by gabbro with a thickness of about $2 \mathrm{~m}$. Along the contact with the gabbro, orthopyroxenite is found. Above this gabbro layer horizon, the SDW suite rocks occur intercalated with gabbroic layers. $I V-3$ The SDW suite

The SDW suite occurs as layers in the MHL harzburgite. The chromian spinel in the SDW has an oblate ellipsoidal form with a slightly Iong axis parallel to the lineation. The thickest layer of the SDW (about $15 \mathrm{~m}$ in thick. ness) occurs in a harzburgite layer in the middle of the Horoman complex (Fig. 1). The harzburgite becomes comparatively spinel-rich and orthopyroxene-poor near the contact with dunite of the SDW. The upper contact with the harzburgite is sharp, marked by an abrupt decrease of the amount of spinel. The thickness of the upper transition zone between harzburgite and dunite is almost a few centimeters (very rarely up to ten centimeters). On the other hand, the lower contact is more gradational than the upper one; the transiton zone is several tens of centimeters in thickness.

The thickest dunite layer consists of a central wehrlitic zone with a thickness of a few meters and clinopyroxene-poor dunitic margins. The marginal dunite is often smoky gray in color, whereas the central wehrlitic dunite is yellow in hand specimens. Thin spinel-rich wehrlitic bands ( $a$ few centimeters in thickness and several meters in length) often occur in the dunitic part.

Dunite of the SDW is usually deformed to various degrees and usually shows porphyro. clastic texture (Mercier and Nicolas, 1975). The porphyroblast strongly elongated and is often a few centimeters in length and the size of neoblast ranges from 0.14 to $0.36 \mathrm{~mm}$. The porphyroblast olivine has abundant relics of fluid inclusions (Hirai and Arai, 1987) and sometimes has $\mathrm{CaCO}_{3}$ inclusions. Spinel grains often show pull-apart structure and have fractures filled with neoblast-size olivine grains. Displacement of cut pieces along the fractures in the spinel grain is rarely observed. Ti-pargasite is sometimes accompanied with spinel grain and is interstitial to olivine grains. A vein which consists of fine grains of $\mathrm{Tj}$-pargasite and spinel is found in the SDW. Sulfide sometimes occurs, accompanied by spinel grains.

Similar-structured but thinner dunite bands, which consist of coarse smoky-gray olivine grains $(20 \mathrm{~cm} \times 10 \mathrm{~cm}$ at maximum), are found in harzburgite layers of MHL. One of them, about 10 to $15 \mathrm{~cm}$ in thickness and at least $5 \mathrm{~m}$ in length, has a spinel-rich wehrlitic part in the center. This dunite band contains irregular harzburgite pods in marginal part and has very sharp boundaries with surrounding harzburgite of the MHL suite.

Spinel-rich orthopyroxene-bearing dunite (or dunitic harzburgite) often occurs as comparatively continuous layers in most of normal harzburgite layers of MHL. The dunitic layers can be traced for several meters along strike. The thickness ranges from several centimeters to a few meters.

Dunite intercalated with gabbroic rocks is sometimes found in the upper part of the complex. The contact between gabbroic rocks and 
the dunite is very sharp. The dunite shows equigranular texture. Towards the contact with the gabbroic bands, the color of the spinel tends to become paler, from greenish brown to light brownish green. Adjacent to the very contact with the dunite, the gabbroic rocks include some dunite fragments and clinopyroxene and spinel grains probably derived from the dunite of the SDW suite. The spinel grains in the dunite fragments are surrounded by plagioclase rind, towards which the color of spinel varies from green to slightly brownish green, suggesting a reaction of spinel and melt producing chrome-rich spinel and plagioclase. The xenocrystic dinopyroxene grains have thick orthopyroxene exsolution lamellae.

\section{v. Mineral chemistry}

\section{$V-1$. The MHL suite}

The MHL peridotites show a wide variation of mineral chemistry, which correlates excellently with the modal composition; the Fo content of olivine and the $\mathrm{Cr} /(\mathrm{Cr}+\mathrm{Al})$ atomic ratio ( $\mathrm{CrH}$ ) of discrete spinel decrease with an increase of the modal percentage of pyroxenes (Figs. 2 and 5). The Fo content of olivine ranges from 90.8 to 92.8 in harzburgite, 90.0 to 91.8 in spinel lherzolite and 88.8 to 90.0 in plagioclase lherzolite (Fig. 5). The Cr\# of coarse discrete spinel core ranges from 0.45 to 0.68 in harzburgite, 0.18 to 0.46 in spinel lherzolite and 0.08 to 0.17 in plagioclase lherzolite (Figs. 5 to 7 ). The Cr\# of coarse discrete spinel core systematically increases with a slight increase of the Fo content of olivine (Fig. 5). Whole MHL data make a trend entirely placed within the "olivine-spinel mantle array" of Arai (1987). The NiO content of olivine increases systematically with an increase of the Fo content (Fig. 8). This trend is consistent with the "mantle olivine array" of Takahashi et al. (1987), which represents an olivine

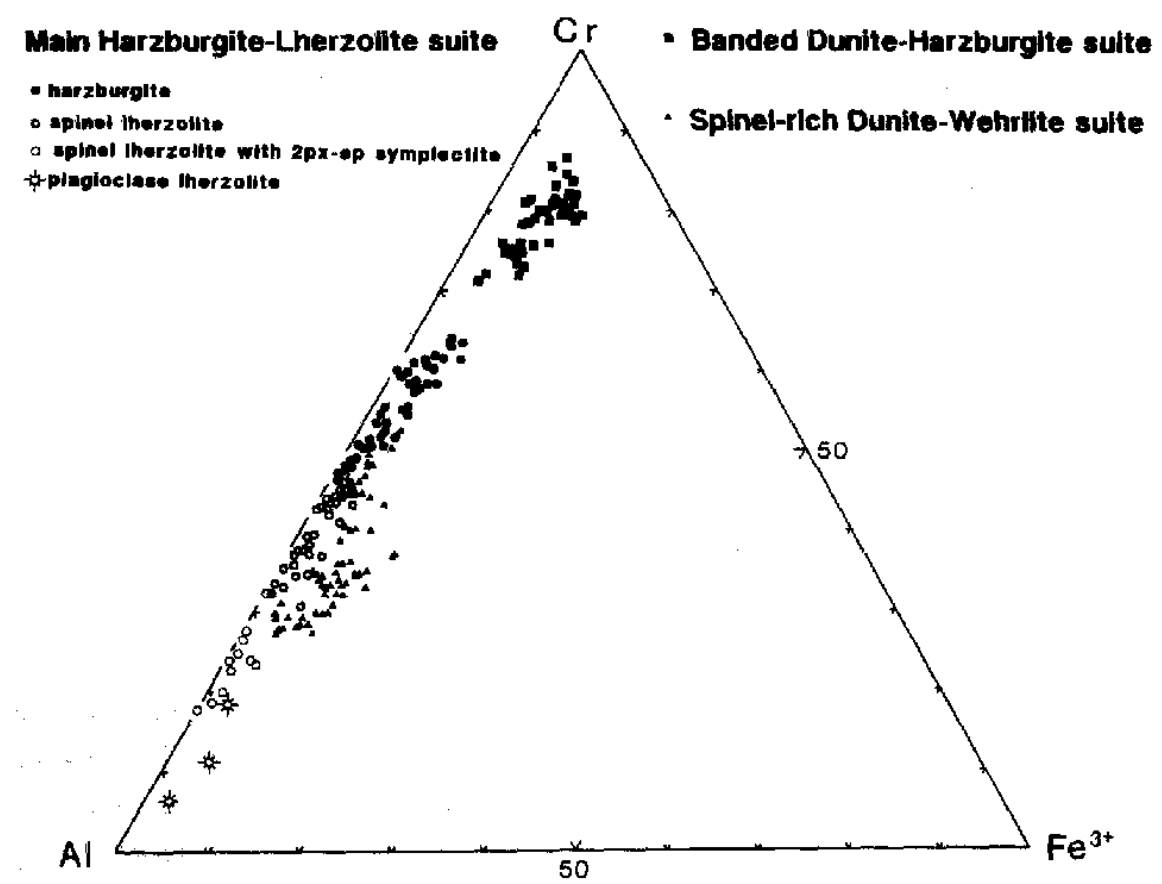

Fig. 6. $\mathrm{Cr}-\mathrm{Al}-\mathrm{Fe}^{3+}$ atomic ratios of chromian spinel in the Horoman peridotites. Note that the SDW spinels and a part of the BDH spinels are slightly $\mathrm{Fe}^{3+}$-rich. 


\section{$\mathrm{TiO}_{2} w t \%$}

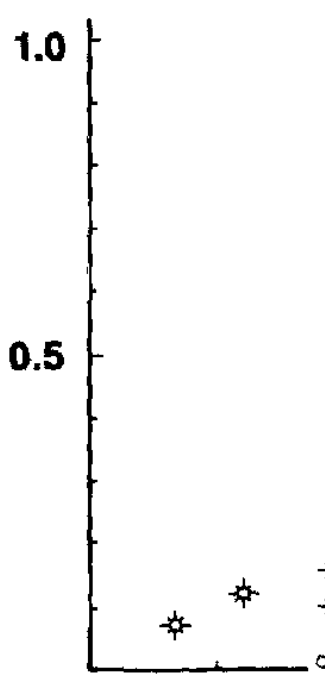

Main Harzburgite-Lherzolite suite

- harzburglte

- spinal therzollte

o spinel therzollte with py-sp symplectite

-4 plagioclase lherzolite

Banded Dunite-Harzburgite suite

- dunite-harzburgite

- dunite-wohrllte

\section{- Spinel-rich Dunite-Wehrlite suite}

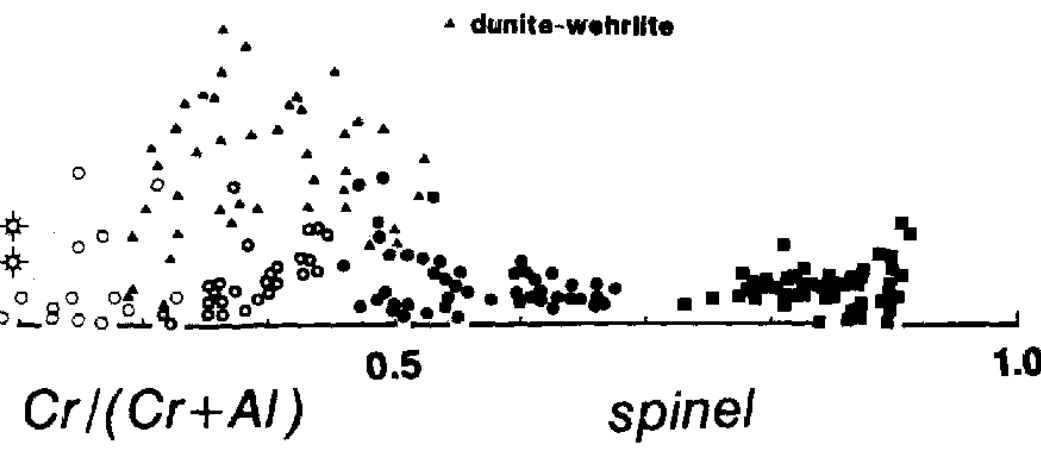

Fig. 7. Relationship between $\mathrm{TiO}_{2}$ wt\% and $\mathrm{Cr} /(\mathrm{Cr}+\mathrm{Al})$ atomic ratio of spinel in the Horoman peridotites. Note that the SDW spinels have relatively high $\mathrm{TiO}_{z}$ content.

compositional range of mantle peridotites. Spinel lherzolite with the pyroxene-spinel symplectite is less refractory than that free of the symplectite (Figs.2 and 5). Chromian spinels in the MHL suite are low in ferric (Fig. 6) and in $\mathrm{TiO}_{2}(<0.3 \mathrm{wt} \%$; Fig. 7). In plagioclase lherzolite, fine-grained spinel closely associated with plagioclase has the $\mathrm{Cr} \#$ around 0.3 , which is much higher than the large discrete one $(<0.17)$ (Figs. 5 to 7 ). The compositional difference suggests a subsolidus reaction between aluminous spinel components and pyroxenes producing plagioclase and olivine in the fine-grained portion. The dunitic part where orthopyroxene seems to be accidentally rare has the same mineral chemistry as the surrounding harzburgite. The individual $\mathrm{min}$ erals of symplectite are slightly different in chemistry from the discrete primary equivalents; the $\mathrm{Cr}_{\#}$ of spinel is lower and the $\mathrm{Ca}$ content of clinopyroxene is slightly higher in symplectite than those of discrete grains. The Cr\# ratio of the bulk of symplectite tends to be lower than that of the discrete spinels (Takahashi and Arai, 1989).

\section{$V-2$. The $B D H$ suite}

The peridotites of $\mathrm{BDH}$ sufficiently far away from the gabbroic rocks have a uniform mineralogy. In the Horoman river area, the Fo content of olivine of the dunite and harz. burgite mostly ranges from 93 to 94 (Fig. 9) and spinel is low in $\mathrm{TiO}_{2}$ (less than $0.18 \mathrm{wt} \%$, mostly nil) (Fig. 7) and high in $\mathrm{Cr}(\mathrm{Cr} \#=0.82-0.88)$ in the massive part (Figs. 6 and 7). The $\mathrm{NiO}$ content of olivine, ranging from 0.35 to $0.40 \mathrm{wt} \%$, is positively correlated with the Fo content (Fig. 8). Olivine in dunite and harzburgite from the banded part exhibits low Fo content $\left(\mathrm{F}_{91.5-92.0}\right)$ and is poor in $\mathrm{NiO}$ content, ranging from 0.25 to 0.33 wt \%. The low $\mathrm{Fo}$ and $\mathrm{NiO}$ contents of olivine in banded part, where gabbroic rocks are not present nearby; may not be due to 


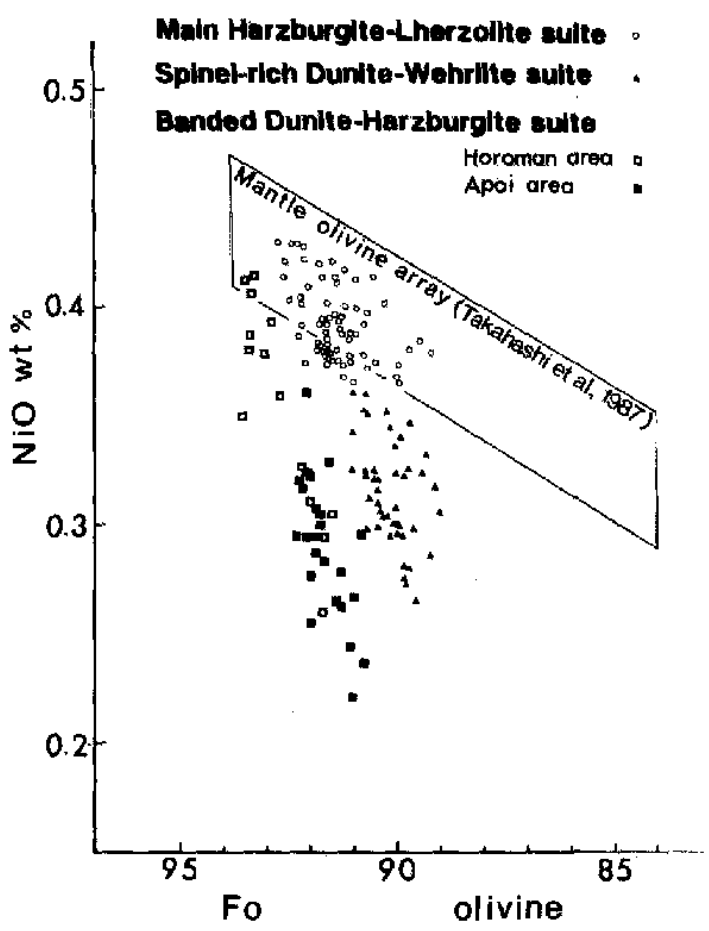

Fig. 8. Relationship between $\mathrm{NiO}$ and Fo content of olivine in the Horoman peridotites. Note that the NiO content in SDW and $\mathrm{BDH}$ olivines show a rapid decrease with a slight decrease of the Fo content, which indicates a cumulus origin.

metasomatism from the gabbro, because $\mathrm{T} i-$ rich minerals are not found in these peridotites, and because spinel is high in $\mathrm{Cr}$ and very low in Ti.

The mineral chemistries of the $\mathrm{BDH}$ change in a systematic way towards the gabbro. The changes may be due to a metasomatism from the gabbroic rocks. The Fo content of olivine decreases to 91.0 , and the $\mathrm{Cr} \#$ of spinel decreases to 0.5 . The $\mathrm{TiO}_{2}$ content of spinel increases up to over $1.0 \mathrm{wt} \%$ and the $\mathrm{Fe}^{3+}$ content of spinel decreases towards the gabbro.

In the Apoi area, the Fo content of olivine is relatively low and constant, ranging from 91.5 to 92.0(Fig. 8). The Cr\# of chromian spinel ranges from 0.73 to 0.87 (mostly higher than
0.76 ) and the $\mathrm{TiO}_{2}$ content is lower than 0.34 wt\% (mostly nil). Near the gabbro bands the mineral chemistry abruptly changes; the Fo content of olivine decreases to about 89.0 , the $\mathrm{Cr} H$ of spinel decreases to lower than 0.7 and the $\mathrm{TiO}_{2}$ content of spinel increases up to $0.8 \mathrm{wt} \%$.

The $\mathrm{Ti}$ content of spinel and the $\mathrm{F}_{0}$ and $\mathrm{NiO}$ contents of olivine are discontinuous across the boundary between the MHL and the BDH. The abrupt changes occur within several centimeters. The discontinuity of the $\mathrm{NiO}$ content is especially evident (Fig. 9). The Cr\# of spinel in the underlying harzburgite of $\mathrm{MHL}$ suite, however, gradually increase towards the $\mathrm{BDH}$ suite (Fig.9). In terms of the olivine composition, the MHL data are confined in the "mantle olivine array" of Takahashi et al. (1987), but those of the BDH are seriously deviated from it (Fig. 8).

\section{$V-3$ The $S D W$ suite}

The peridotite of SDW contain Ti-rich and relatively aluminous spinel; the $\mathrm{TiO}_{2} \quad \mathrm{wt} \%$ ranges from 0.12 to 0.87 and the $\mathrm{Cr} \#$ ranges from 0.24 to 0.56 (Fig. 7). The SDW spinels are enriched with $\mathrm{Fe}^{3+}$ relative to those in peridotites of the other suites (Fig. 6). The Fo content of olivine ranges from 88.8 to 91.2 and the $\mathrm{NiO}$ content is low (from 0.28 to $0.35 \mathrm{wt} \%$ ) (Fig. 8). Those characteristics are common to all peridotites of the SDW suite.

The mineral chemistries of SDW and surrounding harzburgite of the MHL show systematic changes. Fo content of olivine is almost constant in the harzburgite, but the $\mathrm{C}_{\mathrm{r}} \#$ of spinel gradually increases toward the dunite layer and is the highest nearby the contact with the dunite layer. Across the contact, these values change abruptly. In particular the variation is steep at the upper contact of the thickest dunite layer : Fo content of olivine changes from 91.7 in harzburgite to 90.6 in dunite and Cr\# of spinel changes from 0.62 in harzburgite to 0.39 in dunite for only $20 \mathrm{~cm}$ in distance. At 


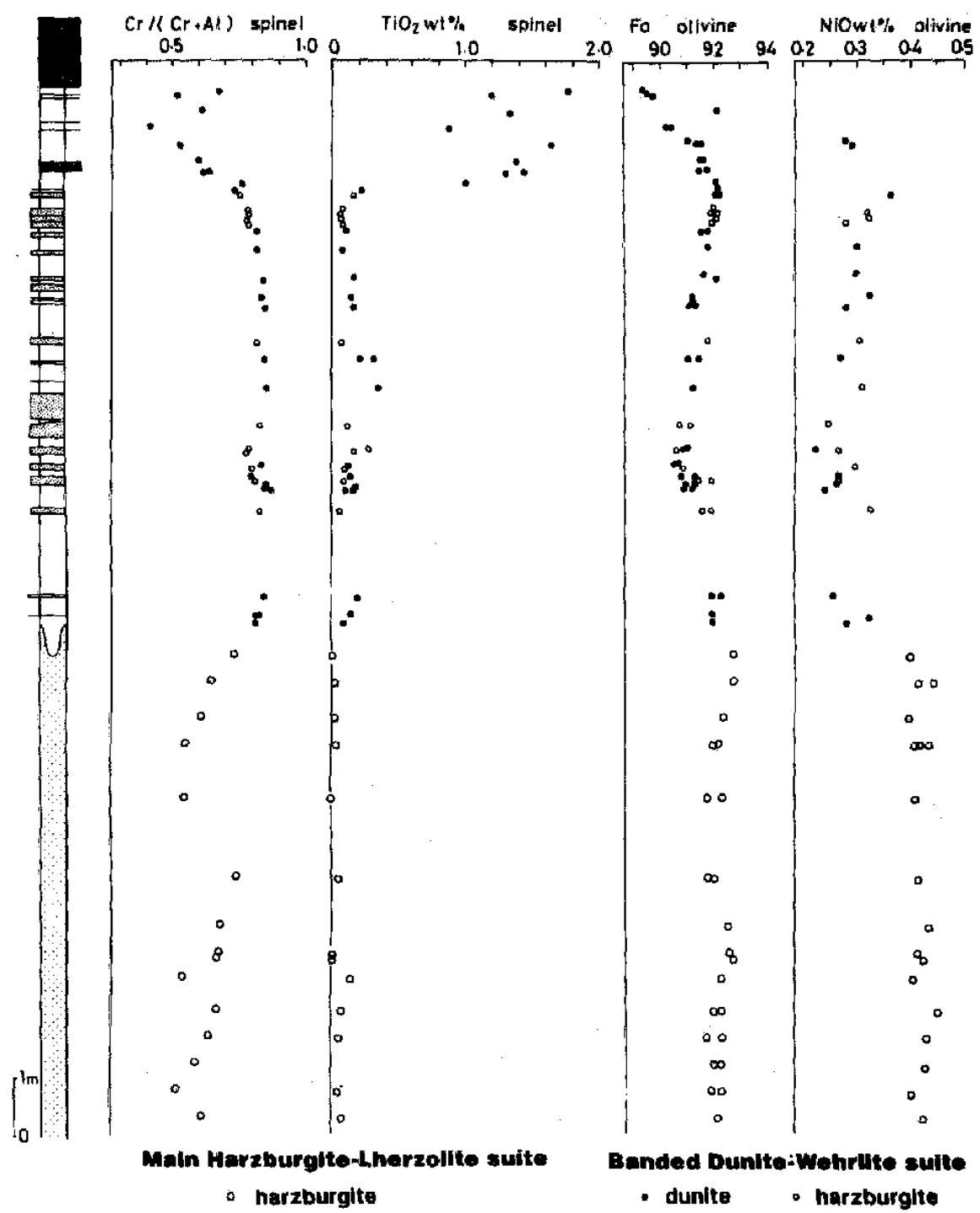

Fig 9. Compositional variation of spinel and olivine in the $\mathrm{BDH}$ and $\mathrm{MHL}$ peridotites in the Apoi area (see Fig. 3). Note the compositional gap between the BDH and MHL rocks.

the just contact, their chemical compositions seem to be almost continuous. The $\mathrm{NiO}$ content of olivine and $\mathrm{TiO}_{2}$ content of spinel, however, have clear gaps at the contact: in the $\mathrm{MHL}$ harzburgite olivine has $0.38 \mathrm{wt} \%$ of $\mathrm{NiO}$ and spinel, less than $0.05 \mathrm{wt} \%$ of $\mathrm{TiO}_{2}$, but in the SDW dunite olivine has $0.32 \mathrm{wt} \%$ of $\mathrm{NiO}$ and spinel, $0.4 \mathrm{wt} \%$ of $\mathrm{TiO}_{2}$. On the other hand, these values change gradually for a meter at the lower boundary. An example of the variation of mineral chemistries of the SDW suite and the MHL suite along the Takinosawa, one of tributaries of the Horoman river in the southeastern part of the complex (Fig. 1), is shown in Fig. 10.

In the thickest SDW layer, the $\mathrm{F}_{0}$ and $\mathrm{NiO}$ contents of olivine slightly decrease towards the center of the layer (Fig. 10). These data 

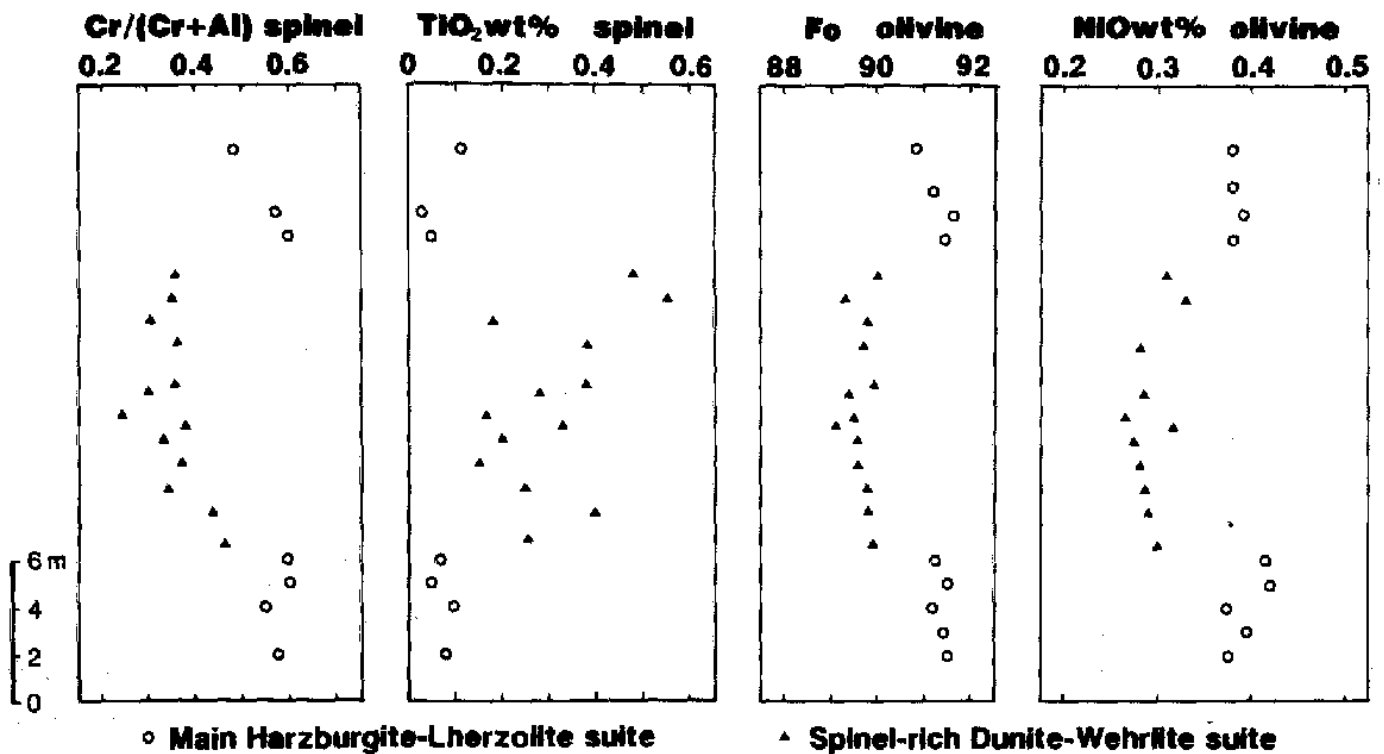

Fig. 10. Compositional variations of spinel and olivine across the SDW layer and MHL harzburgite at Taki-no-sawa (see Fig. 1).

make a fractional crystallization trend starting from a value similar to the surrounding harz. burgite of the MHL, whose olivine composition is in the "olivine mantle array" (Fig. 8). The $\mathrm{TiO}_{2}$ content of spinel, whether increase or decrease in the layer, always tends to be higher near the margin of the layer. This tendency is common to all of the dunite layers of SDW. The $\mathrm{THO}_{2}$ wt\% and $\mathrm{Fe}^{3+}$ of spinel show a positive correlation. The $\mathrm{TiO}_{2}$ content and $\mathrm{Na}_{2} \mathrm{O}$ content of clinopyroxene also shows a positive correlation, though there is no systematic relationships between $\mathrm{TiO}_{2}$ and $\mathrm{Mg} /\left(\mathrm{Mg}+\mathrm{Fe}^{*}\right)$ atomic ratio of clinopyroxene.

The mineral chemistry of the SDW from the thickest layer also shows a slight variation along the strike. The Fo and $\mathrm{NiO}$ content of olivine slightly decrease eastwards, while they are kept constant in the surrounding harzburgite of the MHL.

Thin dunite layers in the harzburgite have mineralogical characteristics similar to the thickest dunite layer; the Fo content of olivine and the $\mathrm{Cr} \#$ of spinel are the same as that of olivine at the surrounding harzburgite, but $\mathrm{TiO}_{2}$ content of spinel is higher than that of harzburgite. Spinel from spinel-rich dunitic layer is also richer in $\mathrm{TiO}_{2}$ than that from the surrounding normal harzburgite.

The peridotites of the SDW banded with gabbroic rocks from upper part of the complex have an almost uniform composition similar to the thickest layer. The $\mathrm{Cr}$ of spinel, however, sharply decreases in a few centimeters towards the contact with the gabbroic rocks.

\section{Discussion}

The mineralogical variations of the MHL suite have characteristics for residual peridotites after various degree of melt extraction (Figs. 5 and 8). Takahashi and Arai (1989) suggested that two-pyroxene spinel symplectite is a garnet pseudomorph. Their interpretation is based both on the polygonal outline of symplectite inclusion in the orthopyroxene and on chemical characteristics of symplectite. Some bulk composition of symplectite have the same composition as the reaction product 
between garnet and olivine, but some disagree with it to various degrees. The most fertile peridotite (plagioclase peridotite) of the MHL suite has symplectite of the former type. They also found that plagioclase-rich seams and olivine-spinel-plagioclase symplectite in plagioclase lherzolite were produced by a subsolidus reaction between aluminous spinel and two pyroxenes. Increasing the degree of refractoriness of the peridotite, the bulk comopsition of symplectite tends to be deviated from the composition of garnet+olivine. Genetical consideration on the origin of the symplectite (Taka. hashi and Arai, 1989) may indicate that the MHL peridotites had been formed by meltsubtraction process from some garnet-bearing peridotite(s).

The BDH suite has mineralogical and textural discontinuities with the MHL harzburgite (Figs. 5, 8 and 9). These facts indicate that the $\mathrm{BDH}$ peridotite has a distinct origin from the MHL peridoties. The BDH suite is probably exotic blocks in the MHL suite. The BDH peridotites make a fractionation trend in $\mathrm{Fo}_{0}$ $\mathrm{Cr} \#$ and Fo-NiO diagrams (Figs. 5 and 8). The $\mathrm{BDH}$ peridotites from the Horoman river area occupy the less fractionated part than those from the Apoi area (Fig. 8). Some ophiolites such as the Papuan ophiolites (England and Davies, 1973 ; Jaques, 1981) and the Horokanai ophiolite, Kamuikotan belt (Ishizuka, 1987) have olivine-orthopyroxene cumulates similar to the BDH peridotites. The olivine and spinel compositions of the $\mathrm{BDH}$ peridotites are similar to those of the phenocryst pairs in the high magnesian andesite and related rocks (Arai and Takahashi, 1986). It is inferred, therefore, that the BDH suite peridotites are early cumulates from this kind of magma.

The SDW suite has a characteristic modal composition such as enrichment in spinel and clinopyroxene. The mineral chemistry, such as the low Ni content of olivine (Fig. 8) and high
$\mathrm{TiO}_{2}$ content in spinel aiso characterizes the SDW suite. An increase in degree of partial melting results in a decrease of modal amounts of clinopyroxene in residual peridotites (e.g., Dick and Fisher, 1984). As Arai (1984) reported from Sangun and Kamuikotan residual harzburgite, the modal abundance of spinel decreases with an increase of degree of partial melting. If dunite of the SDW represents residual peridotite of very high degree of partial melting, it should be poorer in spinel and clinopyroxene than harzburgite of the MHL. Takahashi et al. (1987) indicated that olivines of the residual peridotites from upper mantle are plotted in a limited area on Fo-NiO dia. gram. It is widely accepted that cumulus olivine contains lower $\mathrm{NiO}$ content than resid. ual one (e.g., Sato, 1977; Takahashi, 1986) because $\mathrm{Ni}$ is highly compatible. These characteristics of the SDW strongly indicate that the SDW peridatites are of cumulus origin.

The mode of occurrence that the dunite of the SDW always exists in the middle of the harzburgite layer of the $\mathrm{MHL}$, combined with the above mentioned mineralogical characteristics and continuous mineralogical variation from the surrounding harzburgite to the SDW, strongly supports the idea that the SDW is a cumulate from magma segregated from the MHL harzburgite. This fact indicates that considerable amount of melt was segregated towards the center of harzburgite zones of the MHL, not towards the layers of plagioclase lherzolite.

It has to be considered, therefore, that the peridotites of the MHL suite were formed by various degrees of partial melting and/or of melt extraction from the fertile primary peridotite (=the present plagioclase Iherzolite). The variation in degree of partial fusion has to be locally very steep from the plagioclase therzolite towards the harzburgite layers. Several possibilities for the local increase of degree of 
partial melting and/or melt extraction include 1) lowering of solidus by addition of fluid, 2) increasing of temperature by passage of hightemperature melt from deeper part, 3) decreasing of pressure by formation of cracks.

These three possibilities are, however, not independent of each other; the crack forma tion may be induced by influx of fluid and melt (e.g., Nicolas and Jackson, 1982). The third possibility is of essential importance.

The sharp boundaries between the SDW cumulate and the surrounding residual harzburgite of the MHL strongly indicate the involvement of cracks. Melt extraction can be induced by the crack formation which caused a local pressure decrease (Sleep, 1988). This local pressure decrease can lower the solidus temperature and enhance local melting along the cracks. Along these cracks high-temperature melt and/or fluid of deeper origin can be transported to promote further melting by heating and/or lowering the solidus. Importantly, partial melts are sucked and segregated towards the cracks by local pressure release.

It is concluded that the melt segregation and formation of the layering of the MHL and SDW suites were caused by the crack formation. The melt segregation towards the crack caused selective depletion of the surrounding peridotites. Upon subsequent cooling, olivine was crystallized first from the segregated melt on the crack wall forming dunite. In the final stage of the solidification of the melt formed the SDW suite.

Spinel-rich dunitic harzburgite zones, which are found in almost all harzburgite layers of the MHL, were formed by the similar mechanism to form the SDW, although small in scale.

The Horoman complex may have been formed in the upper mantle where partial melting, melt segregation through cracks, cooling, crystallization and deformation continuously occur. One possible tectonic situation of the formation of the Horoman complex is the uppermost mantle where a mantle plume uprises and spreads horizontally (Rabinowicz et al., 1984, 1987). The BDH peridotites might be fragments of pre-existing lithosphere captured by the uprisen and rotated mantle flow.

\section{CONCLUSIONS}

1. The Horoman peridotite complex is composed of three peridotite suites; the Main Harzburgite-Lherzolite (MHL) suite, the Spinel-rich Dunite-Wehrlite (SDW) suite and the Banded Dunite-Harzburgite $(\mathrm{BDH})$ suite.

2. The Main Harzburgite-Lherzolite suite consists of harzburgite, spinel lherzolite and plagioclase therzolite. They are residual per. idotites which were formed by various degrees of melting and melt extraction. Two-pyroxene spinel symplectite, which occurs in spinel and plagioclase lherzolite, is interpreted to be a chemically modified garnet pseudomorph. The primitive MHL peridotite is a garnet peridotite, whose chemistry is almost equivalent to the plagioclase lherzolite.

3. The Spinel-rich Dunite-Wehrlite suite consists of dunite and wehrlitic dunite. This suite occurs in the MHL harzburgite as layers with sharp boundaries without exception. Mode of occurrence and chemical characteris. tics of the SDW indicate that the SDW is a cumulate from the magma segregated from the MHL peridotites. Origin of the SDW suggests that large amount of melt was segregated towards a crack around which the MHL harz. burgite was formed.

4. The Banded Dunite-Harzburgite suite consists of dunite, harzburgite and olivine orthopyroxenite. They make a conspicuous modal and/or phase layering with sharp boundaries. The $\mathrm{BDH}$ suite peridotites occur as small discontinuous bodies in the upper part of the MHL suite. They may be fragments of pre-existing cumulus lithospheric mantle 
captured by the upwelling MHL.

Acknowledgements: The writer wishes to express her hearty appreciation to Prof. Shoji Arai, Kanazawa Lniversity, for his guidance, encouragement and discussion. She expresses her deep thanks to Prof. Masaaki Obata, Kumamoto University, for discussion and encouragement, to Prof. Eiich Takahashi, Tokyo Institute of Technology, for encouragement and supply of unpublished data, to Dr. Kazuhito Ozawa, University of Tokya, for his helpful discussion. She is much indebted to Mr. Hideto Yoshida, University of Tokyo, Mr. Norimasa Nishida, Cemical Analysis Center, the University of Tsukuba, Dr. Masahiro Aoki and Dr. Tetsuro Urabe, Geological Survey of Japan, for their help for microprobe analysis.

\section{References}

Araj, S. (1984), Igneous mineral equilibria in some alpine-type peridotites in Japan. In Materials Science of the Earth's Interior (Sunagawa, I. Ed.), pp. 653, Terra Sci. Publishing, Co., Tokyo, 445-460,

Araj, S. (1987), An estimation of the least depleted spinel peridotite on the basis of olivine-spinel mantle array. Neues Jb. Mineral. Mh., 8, 347354.

Arai, S. and Takahashi, N. (1986), Petrographical notes on deep-seated and related rocks (4) Highly refractory peridotites from Horoman ultramafic complex, Hokkaido, Japan. Ann. Rep, Inst. Geosci. Univ, Tsukuba, 12, 76-78.

Dick, H.J.B. and Fisher, R.L. (1984), Mineralogic studies of the residues of mantle melting: abyssal and alpine-type peridotites. In Kimberlites II : mantle and crust-mantle relationships (Kornprobst, J. Ed.), pp. 393, Elsevier, Amsterdam, 295-308.

England, R.N. and Davies, H.L. (1973), Mineralogy of ultramafic cumulates and tectonites from Eastern Papua. Earth Planet Sci. Lett. 17, $416-425$.

Hirai, $\mathrm{H}$, and Arai, S. (1987), $\mathrm{H}_{2} \mathrm{O}-\mathrm{CO}_{2}$ fluids supplied in alpine-type mantle peridotites: electron petrology of relic fluid inclusions in olivines. Earth Planet. Sci. Lett, 85, 311-318. Ishizuka, H. (1987), Igneous and metamorphic petrology of the Horokanai Ophiolite in the Kamuikotan Zone, Hokkaido, Japan : A synthetic thesis. Mom. Fuc. Sci, Kochi Unip. Ser. E, Geol. 8, 1-70.

Jaques, A.L. (1981), Petrology and petrogenesis of cumulate peridotites and gabbros from the Marum ophiolite complex, northern Papua, New Guinea. J. Petrol. 22, 1-40.

Komatsu, M., Miyashita, S. and Arita, K. (1986), Composition and structure of the Hidaka metamorphic belt, Hokkaido-historical review and present status-. Monogr. Assoc. Collab. Japan, 31, 189-203. (in Japanese with English abstract)

Kushiro, I. and Yoder, H.S. (1966), Anorthite-forsterite and anorthite-enstatite reactions and their bearing on the basalt-eclogite transformation. J. Petrol, 7, 337-362.

Miyashiro, A. (1961), Evolution of metamorphic belts. J. Petrol., 2, 277-311.

Mercier,J.C.C. and Nicolas, A. (1975), Textures and fabrics of upper-mantle peridoties as illustrated by xenoliths from basalts. J. Petrol, 16, $454-487$.

Nagasaki, H. (1966), A layered ultrabasic complex at Horoman, Hokkaido, Japan. J. Fac. Sci. Univ. Tokyo, 16, 313-346.

Nicolas, A. (1986), A melt extraction model based on stractural studies in mantle peridotites. $J$. Petrol., 27, 999-1022.

Nicolas, A. (1989), Structures of ophiolites and dynamics of oceanis lithosphere. pp. 367, Kluwer Academic Publishers, Dordrecht.

Nicolas, A. and Jackson, M. (1982), High temperature dikes in peridotites; origin by hydraulic fracturing. J. Petrol., 23, 568-582.

Niida, K. (1974), Structure of the Horoman ultramafic mass of the Hidaka metamorphic belt in Hokkaido, Japan. J. Geol. Soc. Japan, $80,3 \mathfrak{I}-44$.

Niida, K. (1975), Texture of olivine fabrics and the Horoaman ultramafic rocks, Japan. J. Assoc. Mineral. Petrol. Econ. Geol., 70, 265-285.

Niida, K. (1984), Petrology of the Horoman ultramafic rocks. J. Fac. Sci. Hokkaido Univ., Ser. IV, 21, 61-81.

Obata, M. and Nagahara, N. (1987), Layering of alpine-type peridotite and the segregation of partial melt in the upper mantle. J. Geophys. Res. 92, 3467-3474.

Rabinowicz, M., Nicolas, A. and Vigneresse, J.L. (1984), A rolling mill effect in asthenosphere beneath oceanic spreading centers. Earth Planet. Sci. Lett, 67, 97-108. 
Rabinowicz, M., Ceuleneer, G. and Nicolas, A. (1987), Melt segregation and flow in mantle diapirs below spreading centers: evidence from the Oman ophiolite. J. Geophys. Res, 92, $3475-3486$.

Sato, H. (1977), Nickel content of basaltic magma : identification of primary magmas and measure of the degree of olivine fractionation. Lithos, 10, 113-120.

Sleep, N.H. (1974), Segregation of magma from a mostly crystalline mush. Geol. Soc. Am. Bull., 85, 1225-1232.

Sleep, N.H. (1988), Trapping of Melt by Veins and Dikes. I. Geophys. Res, 93, 10255-10272.

Takahashi, E. (1986), Origin of basaltic magmas: implications from peridotite melting experiments and an olivine fractionation model. Bull. Volcanol. Soc. Japan, 30, 17-40. (in Japanese with English abstract)

Takahashi, E., Uto, K. and Schilling J.G. (1987), Primary magma compositions and $\mathrm{Mg} / \mathrm{Fe}$ ratios of their mantle residues along $\mathrm{Mid}$ Atlantic Ridge $29^{\circ} \mathrm{N}$ to $73^{\circ} \mathrm{N}$. Tecnical Report of ISEI, Okayama Univ., 1 4.

Takahashi, N. (1988MS), The Horoman peridotie
Mass, the Hidaka belt, Hokkaido, Northern Japan; A complex of three kinds of peridotie suites. Unpublished M. Sc. thesis, Univ. Tsukuba, pp. 135.

Takahashi, N. (1991), The evolutional history of the uppermost mantle of an arc system: petrology of the Horoman massif, Japan. In Ophiolite Genesis and Evolution of Oceanic Lithosphere: Proceedings of Oman ophiolite Symposium, 1990. (Peters, Tj. Ed.), Kuluwer Academic Publishers, Dordrecht. 197-208

Takahashi, N. and Arai, S. (1989), Textual and chemical features of chromian spinel-pyroxene symplectites in the Horoman peridotites, Hokkaido, Japan. Sci. Rep. Inst. Geosci. Univ. Tsukuba. Sec. B, 10, 45-55.

Takahashi, N., Arai, S. and Murota, Y. (1989), Alkali metasomatism in peridotite complexes from the Hidaka belt, Hokkaido, northern Japan. J. Geol. Soc. Japan. 95, 311-329. (in Japanese with English abstract)

Tazaki, K., Ito, E. and Komatsu, M. (1972), Experimental study on a pyroxene-spinel symplectite of high pressures and temperatures. J. Geol. Soc. Japan, 78, 347-354.

\section{筧満かんらん岩体を構成する 3 種類のかんらん岩類の起源； 上部マントルにおけるメルトの形成・分離・固結プロセス}

沅満岩体は 3 種類の異なる起源のかんらん岩系列一とけ残り物質である Main Harzburgite-Lherzolite (MHL) 系列怙よび各々異なるマグマからの集積岩起源であるSpinel-rich Dunite-Wehrlite (SDW) 禾 列，Banded Dunite-Harzburgite $(\mathrm{BDH})$ 系列一が構成されている。MHL 系列は层体の大部分を占め 漸移境界をすつハルッバージャイト〜斜長石レールゾライトの層状の岩塊である。ざくる石の分解物であ ると考光られている輝石一スビネル・シンプレクタイトはスビネルー斜長石レールソライト中にのみ库す

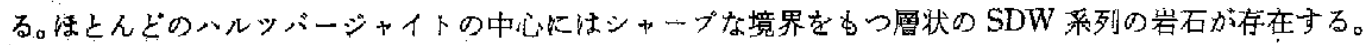
産状，化学組成の检討からSDW 系列はMHL 系列の岩石から分離したメルトからの結晶集積により形成 されたことが判明した。メルトの分離はクラックの形成によって引き起こされた可能性が高い。BDH 系列

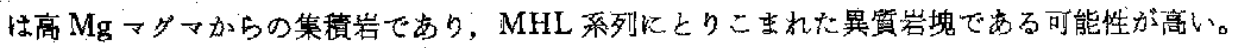

